\title{
The Use of Video as an Aid for the Construction of CLIL Pre-service Teachers' Identity'
}

\author{
Ma Elena Gómez Parra \& Cristina Díaz Martín \\ Universidad de Córdoba \\ elena.gomez@uco.es \& z62dimac@uco.es \\ https://dx.doi.org.10.12795/futhark.2019.il4.03
}

Fecha de recepción: 21.09.2017

Fecha de aceptación: 15.10.2017

\begin{abstract}
The use of video as an aid technique can help pre-service teachers to observe their teaching practice as well as to foster discussion among colleagues (though studies focusing on video within a CLIL context can scarcely be found in the literature). Nevertheless, the way pre-service teachers build their professional identity and whether or not they feel 'as a CLIL teacher' remains unclear. This aspect could be important for teachers not only in order to build their identity as CLIL teachers, but also to improve their teaching practice if it is used as feedback to improve classroom techniques. Therefore, video could stand as a professional tool to reflect on teaching practice as well as on the building of their professional identity as CLIL teachers. In sum, video is presented as a potential powerful tool to enhance CLIL teaching practice by means of the observation and reflection about teachers' lectures. In addition, video can assist on the analysis of CLIL teaching in order to improve the praxis of this approach.
\end{abstract}

Key words: CLIL, CLIL teachers, identity, teacher training, video.

\section{El uso del vídeo como ayuda para la construcción de la identidad de maestros AICLE en formación}

Resumen: El uso del vídeo como técnica puede ayudar a maestros en formación a observar su práctica docente, así como fomentar la discusión entre compañeros (aunque los estudios centrados en el vídeo en contextos AICLE aparecen escasamente en la literatura). Sin embargo, la forma en la que el docente en prácticas construye su identidad profesional y si se siente o no como un 'maestro

\footnotetext{
I This paper has been supported by Plan Propio de Investigación de la Universidad de Córdoba thanks to the award of a competitive pre-doctoral contract.
} 
AICLE' no está del todo clara. Este aspecto podría ser importante para el profesorado, no solo para la construcción de su identidad como docentes AICLE, sino también para mejorar su práctica de aula si se usa como retroalimentación para la mejora de técnicas pedagógicas. Por lo tanto, el vídeo podría ser una herramienta profesional para la reflexión de la práctica educativa, así como para la construcción de la identidad profesional del docente AICLE. En resumen, el vídeo se presenta como una herramienta potente para la mejora de la práctica educativa mediante la observación y reflexión de la praxis docente. Además, el vídeo puede ayudar en el análisis de la enseñanza AICLE para mejorar la implementación de este enfoque.

Palabras clave: AICLE, profesorado AICLE, identidad, formación docente, vídeo.

Sumario: I. Introduction. I.I. Research aims and questions. 2. Theoretical Review. 2.I. Methodological Procedure for the Selection of the Literature. 3. State of the Art / Theoretical Background. 3.I. The use of video in CLIL. 3.2. Video as a tool to construct the identity of CLIL teachers. 4. Methodological design. 5. Expected Results. 6. Discussion.

\section{Introduction}

This paper will review the state of the art on the use of video within a Content and Language Integrated Learning (CLIL) context from which it will delve the idea to use it as an aid to help pre-service teachers working within this approach to construct their professional identity. Then, as a first methodological phase, an exhaustive review on the specialized literature was carried out to inquiry about the identity of CLIL teachers and the way they construct their professional identity. Then, this study will establish the theoretical and methodological bases to use video as a tool for teacher training.

This paper is structured as follows: Firstly, a thorough literature review is developed, from which our theoretical underpinnings will be established. Then, the methodological procedure is described, whose steps can be followed to carry out a well-planned analysis of observation and reflection by pre-service CLIL teachers in order to help them: a. Build a specific professional identity as CLIL teachers. b. Improve their CLIL teaching practice.

Therefore, the first step herein was to identify the main keywords of this piece of research, whose main goal was to study the use of video to support teacher training, which desirably would be an aid to help them to construct their CLIL teachers' professional identity. Thus, "Content and Language Integrated Learning", "video", "teacher identity" and "teacher training" were agreed as the primary descriptors for this review by researchers. After that, the study was 
complemented by a bibliographical search to find the most relevant documents on the topic. Then, the findings of this literature research were deeply discussed.

\section{I.I. Research aims and questions}

The main aim of this review is to show how video can help to the construction of the professional identity of CLIL pre-service teachers, at the same time that it can also be an aid to identify possible unwanted mistakes by teachers, so that they can improve their praxis of CLIL.

Then, the research questions in this study were established as follows:

I. Do CLIL teachers have a professional identity?

2. Does video help CLIL teachers build their professional identity?

3. How can video help pre-service CLIL teachers in the construction of their professional identity?

\section{Theoretical review}

2.I Methodological procedure for the selection of the literature

Our research was carried out from an exhaustive literature review on video and CLIL teachers' identity. To meet this goal, the Web of Science (WOS), Scopus, and Education Resources Information Center (ERIC) were scrutinized. These databases are commonly used for educational research because they collect a major number of indexed and relevant documents in the area.

Then, a research strategy was established where inclusion/exclusion criteria were applied (see Table I) to select the most relevant documents on CLIL, video, teacher identity and teacher training. Consistent information from these analyses was examined to answer the research questions posed above. 


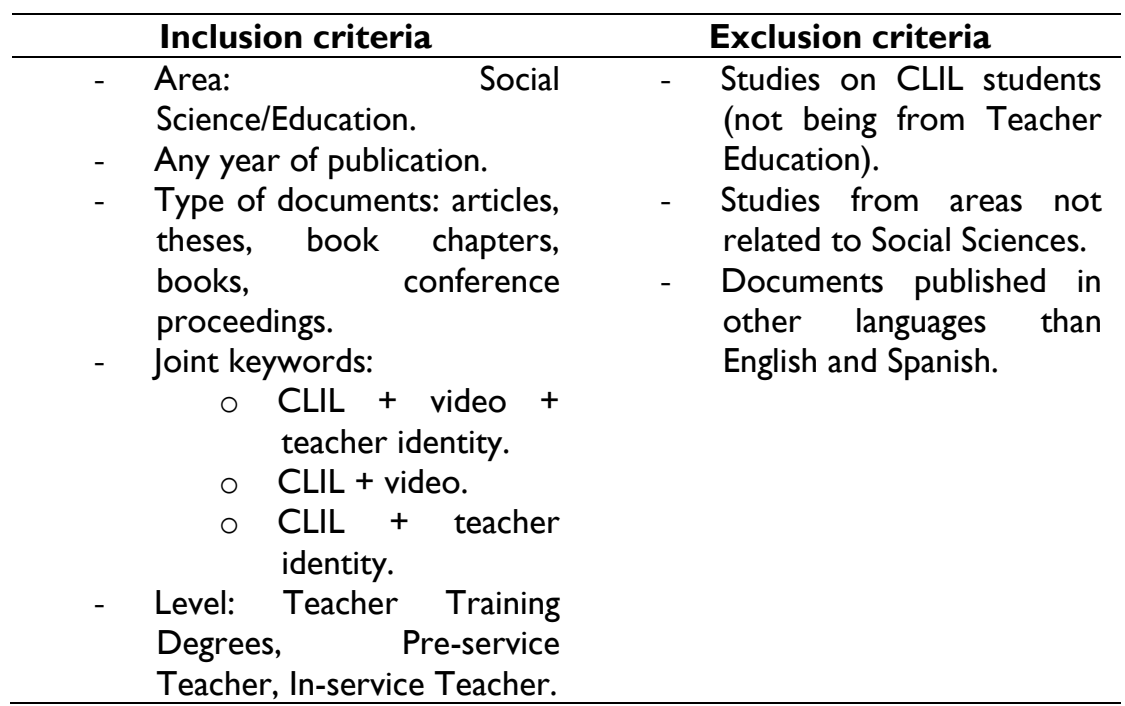

Table I. Inclusion/Exclusion criteria.

After this search in ERIC, WOS and Scopus, 25 documents meeting these inclusion criteria were considered as suitable for our study to answer our research questions, whereas nine documents were dismissed. Moreover, a complementary search was developed to increase the number of documents we would study for our literature review. Additionally, another complementary search in other less relevant data bases was carried out to review possible scientific documents not included in the main data bases used before (i.e. WOS, Scopus and ERIC).

Finally, the results of our search for this literature review are shown in Table 2 below, where the complete recording carried out can be seen in order to analyse the relationship between CLIL, video and teacher identity (as key topics), and also to answer the research questions of this study. 


\begin{tabular}{|c|c|c|c|}
\hline $\begin{array}{c}\text { AUTHOR(s)/ } \\
\text { YEAR }\end{array}$ & $\begin{array}{l}\text { AIMS/PURPOSES } \\
\text { OF THE STUDY }\end{array}$ & KEYWORDS & $\begin{array}{c}\text { HOW IT IS RELATED TO } \\
\text { EITHER VIDEO IN CLIL } \\
\text { OR THE IDENTITY OF } \\
\text { CLIL TEACHERS }\end{array}$ \\
\hline $\begin{array}{l}\text { Cammarata \& } \\
\text { Tedick, } \\
(20 \text { I2) }\end{array}$ & $\begin{array}{l}\text { To suggest } \\
\text { teachers to } \\
\text { integrate content } \\
\text { and language in } \\
\text { their instruction. }\end{array}$ & No keywords. & $\begin{array}{l}\text { Importance of } \\
\text { transforming the identity } \\
\text { of teachers into an } \\
\text { identity of CLIL } \\
\text { teachers. }\end{array}$ \\
\hline $\begin{array}{l}\text { Cinganotto \& } \\
\text { Cuccurullo } \\
(2015)\end{array}$ & $\begin{array}{l}\text { To study the role } \\
\text { of videos in } \\
\text { teaching and } \\
\text { learning content } \\
\text { in a foreign } \\
\text { language. }\end{array}$ & $\begin{array}{l}\text { CLIL, videos, } \\
\text { critical incident, } \\
\text { teacher training, } \\
\text { reflective } \\
\text { teacher. }\end{array}$ & $\begin{array}{l}\text { Improving CLIL teaching } \\
\text { practice through the use } \\
\text { of video. Using video } \\
\text { annotation tool to } \\
\text { improve teacher training. }\end{array}$ \\
\hline $\begin{array}{l}\text { Coral \& Lleixà } \\
(2016)\end{array}$ & $\begin{array}{l}\text { To identify } \\
\text { teaching } \\
\text { strategies to } \\
\text { improve oral } \\
\text { communication. }\end{array}$ & $\begin{array}{l}\text { Physical } \\
\text { education in } \\
\text { CLIL, second } \\
\text { language } \\
\text { learning, } \\
\text { bilingual } \\
\text { education, } \\
\text { linguistic } \\
\text { competence, } \\
\text { CLIL. }\end{array}$ & $\begin{array}{l}\text { Recording and observing } \\
\text { what happens in the } \\
\text { classroom and making } \\
\text { proposals for } \\
\text { improvements in CLIL. } \\
\text { Video as a tool to } \\
\text { research. }\end{array}$ \\
\hline Coyle (2013) & $\begin{array}{l}\text { Successful } \\
\text { learning from } \\
\text { motivation in a } \\
\text { CLIL context. }\end{array}$ & $\begin{array}{l}\text { CLIL, successful } \\
\text { learning, pupil } \\
\text { voice, class- } \\
\text { based research, } \\
\text { LOCIT. }\end{array}$ & $\begin{array}{l}\text { LOCIT model: analysis } \\
\text { of learning moments in } \\
\text { CLIL lessons. }\end{array}$ \\
\hline $\begin{array}{l}\text { De Graaff, } \\
\text { Koopman, \& } \\
\text { Westhoff } \\
\text { (2007) }\end{array}$ & $\begin{array}{l}\text { To observe and } \\
\text { analyse effective } \\
\text { CLIL teaching } \\
\text { performance. }\end{array}$ & $\begin{array}{l}\text { CLIL, } \\
\text { immersion } \\
\text { education, } \\
\text { Language } \\
\text { pedagogy, } \\
\text { observation } \\
\text { tool, teaching }\end{array}$ & $\begin{array}{l}\text { Using video as a } \\
\text { research tool and also } \\
\text { analysing CLIL lessons. } \\
\text { Video is useful for } \\
\text { teacher training and } \\
\text { reflection on teaching. }\end{array}$ \\
\hline
\end{tabular}




\begin{tabular}{|c|c|c|c|}
\hline $\begin{array}{c}\text { AUTHOR(s)/ } \\
\text { YEAR }\end{array}$ & $\begin{array}{l}\text { AIMS/PURPOSES } \\
\text { OF THE STUDY }\end{array}$ & KEYWORDS & $\begin{array}{c}\text { HOW IT IS RELATED TO } \\
\text { EITHER VIDEO IN CLIL } \\
\text { OR THE IDENTITY OF } \\
\text { CLIL TEACHERS } \\
\end{array}$ \\
\hline & & performance. & \\
\hline $\begin{array}{l}\text { Escobar } \\
\text { Urmeneta } \\
(2013)\end{array}$ & $\begin{array}{l}\text { To observe the } \\
\text { usefulness of a } \\
\text { model in teacher } \\
\text { education } \\
\text { programs on CLIL } \\
\text { in order to } \\
\text { improve teacher } \\
\text { empowerment } \\
\text { through } \\
\text { reflection. }\end{array}$ & $\begin{array}{l}\text { Teacher } \\
\text { education } \\
\text { (TED) models, } \\
\text { teacher-led } \\
\text { enquiry, } \\
\text { classroom } \\
\text { interactional } \\
\text { competence } \\
\text { (CIC), CLIL, } \\
\text { code choice, } \\
\text { internship. }\end{array}$ & $\begin{array}{l}\text { Using video in } \\
\text { educational research and } \\
\text { supporting reflective } \\
\text { teaching. }\end{array}$ \\
\hline $\begin{array}{l}\text { Evnitskaya \& } \\
\text { Morton } \\
\text { (20II) }\end{array}$ & $\begin{array}{l}\text { To show the } \\
\text { relationship } \\
\text { between two } \\
\text { different models } \\
\text { related to the use } \\
\text { of language and } \\
\text { interaction in } \\
\text { CLIL. }\end{array}$ & $\begin{array}{l}\text { CLIL, classroom } \\
\text { interaction, } \\
\text { communities of } \\
\text { practice, } \\
\text { meaning-making, } \\
\text { conversation } \\
\text { analysis, } \\
\text { multimodal } \\
\text { analysis. }\end{array}$ & $\begin{array}{l}\text { The space of CLIL to the } \\
\text { construction of identity } \\
\text { teachers. } \\
\text { Communities of practise. }\end{array}$ \\
\hline $\begin{array}{l}\text { Kontio \& } \\
\text { Sylvén (2015) }\end{array}$ & $\begin{array}{l}\text { To understand } \\
\text { students' oral } \\
\text { language use in } \\
\text { the sort of } \\
\text { language } \\
\text { environment that } \\
\text { arises when } \\
\text { English is the } \\
\text { language of } \\
\text { instruction. }\end{array}$ & $\begin{array}{l}\text { CLIL, classroom } \\
\text { interaction, } \\
\text { language } \\
\text { alternation, } \\
\text { linguistic } \\
\text { ethnography, } \\
\text { microanalysis, } \\
\text { vocational } \\
\text { education. }\end{array}$ & $\begin{array}{l}\text { Collecting data using } \\
\text { video recording and } \\
\text { analysing them. }\end{array}$ \\
\hline $\begin{array}{l}\text { Morton } \\
(2016)\end{array}$ & $\begin{array}{l}\text { To investigate the } \\
\text { relationship } \\
\text { between teacher } \\
\text { cognitions, }\end{array}$ & No keywords. & $\begin{array}{l}\text { Being a CLIL teacher. } \\
\text { Construction of identity } \\
\text { of CLIL teachers. }\end{array}$ \\
\hline
\end{tabular}




\begin{tabular}{|c|c|c|c|}
\hline $\begin{array}{c}\text { AUTHOR(s)/ } \\
\text { YEAR }\end{array}$ & $\begin{array}{l}\text { AIMS/PURPOSES } \\
\text { OF THE STUDY }\end{array}$ & KEYWORDS & $\begin{array}{l}\text { HOW IT IS RELATED TO } \\
\text { EITHER VIDEO IN CLIL } \\
\text { OR THE IDENTITY OF } \\
\text { CLIL TEACHERS }\end{array}$ \\
\hline & $\begin{array}{l}\text { identities and } \\
\text { classroom } \\
\text { practices related } \\
\text { to the integration } \\
\text { of content and } \\
\text { language. }\end{array}$ & & \\
\hline $\begin{array}{l}\text { Pennington \& } \\
\text { Richards } \\
(2016)\end{array}$ & $\begin{array}{l}\text { To review } \\
\text { language teacher } \\
\text { identity. }\end{array}$ & $\begin{array}{l}\text { Language } \\
\text { teaching, } \\
\text { teacher identity, } \\
\text { teacher } \\
\text { learning, } \\
\text { teacher } \\
\text { education, } \\
\text { language } \\
\text { learning, second } \\
\text { language. }\end{array}$ & $\begin{array}{l}\text { Suggesting the necessary } \\
\text { steps to build a specific } \\
\text { identity for second } \\
\text { language teacher. }\end{array}$ \\
\hline $\begin{array}{l}\text { Tavares } \\
(2015)\end{array}$ & $\begin{array}{l}\text { To improve CLIL } \\
\text { teaching in } \\
\text { mathematics } \\
\text { content. }\end{array}$ & $\begin{array}{l}\text { Medium of } \\
\text { instruction } \\
\text { policy, } \\
\text { mathematics, } \\
\text { CLIL, } \\
\text { bilingual(ism), } \\
\text { language across } \\
\text { the curriculum. }\end{array}$ & $\begin{array}{l}\text { Using video-recorded } \\
\text { lessons for the analysis } \\
\text { of } \\
\text { lecturing. }\end{array}$ \\
\hline $\begin{array}{l}\text { Temirova \& } \\
\text { Westall } \\
(2015)\end{array}$ & $\begin{array}{l}\text { To collect videos } \\
\text { to examine } \mathrm{LI} \\
\text { and } \mathrm{L} 2 \text { use in } \\
\text { CLIL classrooms. }\end{array}$ & $\begin{array}{l}\text { CLIL, language } \\
\text { use, teaching } \\
\text { methodology, } \\
\text { English language } \\
\text { learning, } \\
\text { European } \\
\text { Union. }\end{array}$ & $\begin{array}{l}\text { Analysing videos from } \\
\text { CLIL lessons. }\end{array}$ \\
\hline
\end{tabular}

Xanthou To determine the CLIL, L2 Recording and analysing 


\begin{tabular}{|c|c|c|c|}
\hline $\begin{array}{c}\text { AUTHOR(s)/ } \\
\text { YEAR }\end{array}$ & $\begin{array}{c}\text { AIMS/PURPOSES } \\
\text { OF THE STUDY }\end{array}$ & KEYWORDS & $\begin{array}{l}\text { HOW IT IS RELATED TO } \\
\text { EITHER VIDEO IN CLIL } \\
\text { OR THE IDENTITY OF } \\
\text { CLIL TEACHERS }\end{array}$ \\
\hline$(20 I 1)$ & $\begin{array}{l}\text { capacity of } \\
\text { student learning } \\
\text { content through } \\
\text { the medium of L2 } \\
\text { and } \\
\text { simultaneously } \\
\text { exhibit significant } \\
\text { gains in L2 } \\
\text { vocabulary } \\
\text { knowledge. }\end{array}$ & $\begin{array}{l}\text { learning, subject } \\
\text { matter learning, } \\
\text { experimental } \\
\text { study, action } \\
\text { research. }\end{array}$ & $\begin{array}{l}\text { CLIL lessons in order to } \\
\text { view the achievement of } \\
\text { students. }\end{array}$ \\
\hline
\end{tabular}

Table 2. Results of the search for literature review.

The results of this search for literature review underline the idea that video can be considered as a useful tool to research within CLIL contexts. According to Morton, few studies on CLIL teacher identity can be found nowadays in the literature (Evnitskaya \& Morton, 20II; Morton, 2016; Pennington \& Richards, 2016). Evnitskaya \& Morton (20II) discuss the identity of CLIL teachers and Morton (2016) discusses the importance of the identity of CLIL teachers and how video helps them to reflect in their practice within CLIL classrooms.

Nevertheless, and accordingly to the objectives of our literature review, few papers were found related to the use of video as a support to teachers' professional identity construction. Although this literature research included all publication years within educational research, only one paper in 2016 was found to study the relationship between video, CLIL and teacher identity (Morton, 20I6).

\section{State of the art / Theoretical background}

\section{I The use of video in CLIL}

Content and Language Integrated Learning (CLIL) is a dual-focused educational approach in which an additional language is used for the learning and teaching of both content and language (Coyle, Hood, \& Marsh, 2010). CLIL is the new methodology to the teaching of content through a foreign language in Europe, endorsed by the European Commission in 1994. For this reason, it is important to analyse in which ways it is the training of future teachers being developed and whether or not these teachers feel as CLIL teachers, as their professional identity 
can play a fundamental role in the educational setting of $2 \mathrm{I}^{\text {st }}$ century European context. Also, it is necessary to pose fundamental questions, such as how is the CLIL teacher being trained, and which tools (such as video) should help teachers improve their practice within a dual (content and language) teaching context.

A number of authors underline the usefulness of video to collect audiovisual data from teaching contexts. Data collected from videos are analysed in order to improve teacher training (Cinganotto \& Cuccurullo, 2015; De Graaff et al., 2007). Likewise, all articles related to video in CLIL describe the use of this tool to observe and analyse CLIL contexts (Coral \& Lleixà 2016; Coyle, 2013; De Graaff et al., 2007; Escobar Urmeneta, 2013; Kontio \& Sylvén, 2015; Tavares, 2015; Temirova \& Westall, 2015; Xanthou, 20II). Coyle (2013) presents a model named LOCIT where teachers observe and analyse teaching practices. Other articles describe video as a tool to reflect on teaching (De Graaff et al., 2007; Escobar, 2013).

As a result, video is found to be a flexible tool used in CLIL classrooms, which is commonly used to collect a considerable amount of data in educational research. Furthermore, researchers tend to apply video to analyse educational contexts in order to collect more details than with other similar tools (e.g. audios, interviews or questionnaires). Therefore, video within CLIL contexts is formally used in educational research in order to capture CLIL lessons (Coyle, 2013). Therefore, the use of video allows researchers to collect data which are then analysed to meet varied researching goals. For instance, Cinganotto \& Cuccurullo (2015) use video within a CLIL context to improve teacher training. In a similar way, De Graaff et al. (2007) and Escobar (2013) use this tool in CLIL lessons to reflect on teaching practice. In particular, Escobar (2013) presents a case study where a teacher reflects on her own teaching. The analysis of these studies clearly states that video can be a useful researching tool within CLIL contexts. Furthermore, it can prove to be beneficial to both researchers and teachers so as to improve teaching practice. In addition, video within CLIL offers the opportunity to analyse and get specific details on teaching practice that other tools do not have. For instance, we can record and watch CLIL lessons several times, share the recording with other teachers, reflect about these lessons and analyse a specific lesson in order to identify the effectiveness of certain teaching strategies (Coyle, 2013; De Graaff et al., 2007). Nonetheless, reflecting on the support to pre-service teachers regarding the building of their identities as CLIL teachers is one of the most important reasons to use video within CLIL contexts for this study. In the same way, it is among our goals also to use this tool in teacher training programmes in order to improve teaching practice as a helper in the construction of a specific CLIL teacher identity. 
In sum, the use of video as a tool to improve both teaching practice and teacher training within CLIL contexts (Coyle, 2013) proves to be a valuable aid. The literature analysed shows that there are different ways to use video: to research on teaching practice, to reflect on teaching practise, and to improve student learning within CLIL contexts. However, it is important to consider one more use of video: to help CLIL teachers build a specific teaching professional identity.

\subsection{Video as a tool to construct the identity of CLIL teachers}

In this review, authors who study identity within CLIL contexts agree on the need of the construction of a specific professional identity for CLIL teacher trainees (Morton, 2016; Cammarata \& Tedick, 2012; Evnitskaya \& Morton, 20II). According to Cammarata \& Tedick (2012), it is important to integrate content and language to be a CLIL teacher: "I really think...being an immersion teacher is saying: 'Yeah, I'm a content teacher and I'm a language teacher and I need to integrate those two to be effective"' (Cammarata \& Tedick, 2012, p. 258). Improving teacher training could be effective to teaching practices. Likewise, the reflection on practice in teacher training could foster thinking about one's identity as a CLIL teacher.

As stated above, few documents on the professional identity of CLIL teachers were found in our literature review (Morton, 2016; Cammarata \& Tedick, 2012; Evnitskaya \& Morton, 20II). However, it is considered an unexplored and emerging area in educational research. In fact, our literature review shows to be scarce still regarding the establishment of the relationship between video and the identity of CLIL teachers.

Morton (2016) stands as the unique author (up to the moment) relating CLIL, video and identity. In his study, video is used as the main tool to reflect within CLIL contexts, where teachers discuss about their professional practices based on a series of recorded lessons. Additionally, he discusses about the teacher's identity in this context. Therefore, Morton (2016) opens a research line to improve teacher training within CLIL spaces. Moreover, video and professional identity within CLIL are integrated in his research.

Therefore, further research is needed on the use of videos to improve teacher training and the building of the teaching identity within a CLIL space. Whether or not CLIL teachers feel as a different type of professional is one of the main questions in this chapter: Do CLIL teachers show a specific professional identity? According to Morton (2016) reflecting on what are we doing in our CLIL lesson is important to define our identity. For that purpose, specific tools such as video might support teacher training in CLIL lessons (De Graaff et al., 2007). In 
addition, the community of teachers in CLIL contexts can encourage them to reflect on their professional identities (Evnitskaya \& Morton, 20I I).

Video should help us to study and analyse teachers' reactions when they practice self-observation while teaching. This technique, as an essential step of a methodological plan, can definitely support teacher training programmes at the same time that it can contribute to build the specific identity of CLIL teachers. Cammarata \& Tedick (2012) propose the development of specific programmes whose aim is to transform teachers' identities within CLIL. The aim of this paper, thus, is to integrate video as a tool to construct and transform teachers' identities. In the same way, practices in CLIL contexts could be improved by video.

\section{Methodological design}

The methodological design herein aims to support pre-service teachers in the building of their identities as CLIL teachers, based on a thorough literature review as its theoretical background. Studies presenting videos as a tool to improve teacher training are scrutinized, as well as papers focusing on the construction of teachers' identity. Thereby, teaching practices are expected to improve, as well as the positive evolution of pre-service teachers' identities within an academic programme.

The second step in our procedure now is the design of an observation template whose main objective is to analyse a series of recorded lessons within CLIL contexts. In order to integrate this template into an academic program, a validation by experts is required. We used Taylor-Powell \& Steele (1996) as a reference, which we then adapted to be used with pre-service teachers within CLIL contexts. Moreover, Pennington \& Richards (20/6) offer a series of relevant features to build the identity of second language teachers that we also took into consideration. This template, once validated by a panel of experts through the Delphi method, would be used by researchers as well as by pre-service teachers to objectively observe and analyse recorded lessons.

The third methodological step is to plan the academic programme that will be run to do the research. Such planning is holistic as it includes the whole procedure for the recording of the lessons, as well as the appropriate spaces where pre-service teachers might observe their own teaching practices. This step is a keystone of the whole model because it should help pre-service teachers to apply the observation template to analyse their own teaching videos. The procedure herein can be divided into the following sub-steps that are described as:

a. Pre-service teachers prepare for their CLIL teaching sessions. 
b. The setting (classroom) is also prepared accordingly.

c. Pre-service teachers are recorded (short sessions).

d. Sessions are observed by the classroom teacher, the researchers as well as by pre-service teachers with the help of specific software that is used to include specific annotations and register data from this first analysis. The analysis of these recordings is used by pre-service teachers to improve their own performance.

e. Pre-service teachers are recorded during a whole CLIL session.

f. Then, researchers, teachers and pre-service teachers analyse the final recorded lessons.

g. Finally, a common space is created to discuss recordings, where crosscommentaries will be considered a useful tool in the creation of a professional CLIL teaching identity.

Therefore, this step consists of the recording teachers into two phases as they deliver their CLIL lessons during the academic programme, which is analysed once the recording is collected with the aid of specific software for video annotation. According to Cinganotto \& Cuccurullo (2015, p. 53) video annotation allows teachers and learners to interact with video via note-taking, discussions and comments. Therefore, taking notes on video recording could offer pre-service teachers discuss about their lessons. Moreover, pre-service CLIL teachers could reflect on their professional identity.

Lastly, the community where pre-service teachers share and discuss about their professional identity within CLIL contexts remains. In this way, Evnitskaya \& Morton (20II) propose a specific CLIL space to build teachers' identity. This is the theoretical construct that led us to include such space in our methodological design. Furthermore, a deep reflection on self-teaching practise to build their identity as CLIL teachers is expected to occur.

\section{Expected results}

This chapter has reviewed a number of studies which state the importance of teachers' professional identity within CLIL contexts. The main goal of this research is to establish a methodological procedure to help pre-service teachers to learn how to build their professional identity as CLIL teachers. A new horizon where pre-service teachers use video to reflect on their identity is emerging.

Importantly, the academic programme designed herein may help preservice teachers to construct their professional identity. Such programme is purposefully 
addressed to improve teacher training through videos (Cinganotto \& Cuccurullo, 2012). In addition, video is a useful tool to reflect on teaching (De Graaf et al., 2007). Thereby, reflection may be extended to class lessons, as well as to help teachers create their professional identity. Moreover, pre-service teachers are expected to learn how to develop effective CLIL lessons and how to assess them. By recording and observing their own lessons, pre-service teachers would learn to identify unwanted practice mistakes and prevent them from appearing in subsequent lessons. Furthermore, the analysis of these recordings could support them to assess their own teaching practices within CLIL. Therefore, specific software to take notes on video recordings could enhance the assessment of CLIL lessons and improve pre-service teachers' analyses.

Last but not least, the building of CLIL pre-service teachers' identity and the improvement of CLIL teaching are the main expected results. Additionally, the scientific community is expected to pay further efforts on the research of an appropriate and necessary CLIL teacher identity. Therefore, investing in new tools that can be applied within CLIL contexts, such as video, becomes an important goal.

\section{Discussion}

The research questions posed in this chapter focus on the necessity of studying the professional identity of CLIL teachers. The identity of CLIL teachers as related to the use of video is a topic rarely mentioned in the literature, and only those which present the use of video as an aid for the construction of teachers' professional identity point out that this field of research is still unexplored. More importantly though is the fact that to conduct a strong and deep study on the topic could improve teacher training by including supporting programmes to help preservice teachers build their professional identity as CLIL teachers based on selfobservation.

Our methodological procedure designs an academic program which establishes the recordings and analyses of CLIL lessons delivered by pre-service teachers during their training periods. According to Cammarata \& Tedick (2012) teacher training programmes contribute to the discussion about professional identity within CLIL contexts. Therefore, pre-service teacher training within CLIL contexts could be improved by the self-observation methodology herein described. In addition, by following this procedure, pre-service teachers could reflect on their own identity as CLIL teachers, following De Graaff et al. (2007) and Escobar (2013) where we find a whole description of teachers reflecting on teaching through videos. 
This methodology integrates both the recording and analysis of lessons from pre-service teachers within CLIL contexts into an academic programme. The literature analysed highlights the importance of recording CLIL lessons in order to conduct a deep analysis of these (e.g. Coyle's LOCIT model, 2013). Our methodological design, as differently from other articles, connects three important areas: video, professional identity and CLIL. Morton (2016) is the only research that suggests the use of video in order to transform and build teacher identity within CLIL contexts (that is, focusing on pre-service teachers). Teacher training programmes can benefit from this methodology by applying consistent observations to improve CLIL future teaching practices. It is important to focus methodological research on this level as it can help pre-service teachers to build their professional identity before becoming independent teachers.

Therefore, video is a valuable tool to improve teacher training programmes, at the same time that it can foster the construction of CLIL teachers' professional identity.

\section{References}

Cammarata, L. \& Tedick, D.J. (2012). Balancing content and language in instruction: The experience of immersion teachers. The Modern Language Journal, 96(2), 25I-269.

Cinganotto, L. \& Cuccurullo, D. (2015). The role of videos in the teaching and learning of content in a foreign language. Journal of e-Learning and Knowledge Society, II (2), 49-62.

Coral, J. \& Lleixà, T. (2016). Physical education in content and language integrated learning: successful interaction between physical education and English as a foreign language. International Journal of Bilingual Education and Bilingualism, 19(1), 108-126.

Coyle, D. (2013). Listening to learners: an investigation into 'successful learning' across CLIL contexts. International Journal of Bilingual Education and Bilingualism, I6(3), 244-266.

Coyle, D., Hood, P., \& Marsh, D. (2010). Content and language integrated learning. Cambridge University Press, Cambridge.

De Graaff, R., Jan Koopman, G., Anikina, Y., \& Westhoff, G. (2007). An Observation Tool for Effective L2 Pedagogy in Content and Language Integrated Learning (CLIL). The International Journal of Bilingual Education and Bilingualism, 10(5), 603-624. 
Escobar Urmeneta, C. (20/3). Learning to become a CLIL teacher: teaching, reflection and professional development. International Journal of Bilingual Education and Bilingualism, 16(3), 334-353.

Evnitskaya, N. \& Morton, T. (20II). Knowledge construction, meaning-making and interaction in CLIL science classroom communities of practice. Language and Education, 25(2), 109-127.

Kontio, J. \& Sylvén, L.K. (2015). Language alternation and language norm in vocational content and language integrated learning. The Language Learning Journal, 43(3), 27I-285.

Morton, T. (2016). Being a language teacher in the content classroom: teacher identity and content and language integrated learning (CLIL). In S. Preece (Ed.). The Routledge Handbook of Language and Identity (pp. 382-395). Abingdon, England: Routledge.

Pennington, M.C. \& Richards, J.C. (2016). Teacher Identity in Language Teaching: Integrating Personal, Contextual, and Professional Factors. RELC Journal, 47(I), 5-23.

Tavares, N.J. (2015). How strategic use of LI in an L2-medium mathematics classroom facilitates L2 interaction and comprehension. International Journal of Bilingual Education and Bilingualism, 18(3), 319-335.

Taylor-Powell, E. \& Steele, S. (1996). Collecting evaluation data: Direct observation. Program Development and Evaluation. Wisconsin: University of Wisconsin-Extension, I-7.

Temirova, F. \& Westall, D. (2015). Analysis of First and Foreign Language Use in Content and Language Integrated Learning (CLIL) Classrooms. ProcediaSocial and Behavioral Sciences, 178, 217-221.

Valcke, J. \& Tudor, I. (20II). Content and language integrated learning in higher education: selected audiovisual materials for enhancing integration of content and language. EDULEARN I I Proceedings, I438-I 445.

Xanthou, M. (201I). The impact of CLIL on L2 vocabulary development and content knowledge. English Teaching, I0(4), II6-126. 
